\title{
Brine Shrimp Cytotoxic Activity of Morinda elliptica Leaves and Root Crude Extracts
}

\author{
HENRY YUSUFU WAKAWA, FASIHUDDIN BADRUDIN AHMAD, ZAINI BIN ASSIM \\ \& UMARU ISAAC JOHN
}

\author{
Faculty of Resource Science and Technology, Universiti Malaysia Sarawak, \\ 94300 Kota Samarahan, Sarawak, Malaysia \\ *Corresponding author: ntawalhen@yahoo.com
}

\begin{abstract}
This survey was conducted to test for in vivo Brine Shrimp Lethality Assay (BSLA) of Morinda elliptica leaves and root extract after successive maceration in four solvents (n-hexane, dichloromethane (DCM) ethyl acetate and methanol) and cytotoxicity was evaluated in terms of $\mathrm{LC}_{50}$ (lethality concentration). 10 nauplii were placed in different concentrations (in three replicates each) of the plant extracts, after 24 hours the surviving brine shrimp larvae were counted and $\mathrm{LC}_{50}$ was assessed. The result of the survey showed a concentration dependent increment in mortality rate of the brine shrimp nauplii and n-hexane and methanol fractions of the leaves and root extracts were more potent against the brine shrimp with $\mathrm{LC}_{50}$ values of $35.483 \mathrm{ppm}$ and $39.259 \mathrm{ppm}(\mu \mathrm{g} / \mathrm{ml})$ respectively, whereas ethyl acetate of both the extracts exhibited lower potent activity with $\mathrm{LC}_{50}$ values $62.250 \mathrm{ppm}$ and $102.250 \mathrm{ppm}(\mu \mathrm{g} / \mathrm{ml})$ in roots and leaves respectively. These findings indicated that bioactive ingredients are present in the plants that could account for its pharmacological effects.
\end{abstract}

Keywords: Brine shrimp, cytotoxicity, extract, $\mathrm{LC}_{50}$, Morinda elliptica

\section{INTRODUCTION}

Brine shrimp lethality bioassay (BSLA) is a rapid and comprehensive bioassay for the bioactive compounds of natural and synthetic origin, the method was presented by Meyer et al. (1982) as a general assay capable of detecting spectrum of bioactivity present in crude extracts of medicinal plants (Kaniz et al., 2013). The technique is cost effective and can be mastered easily, it requires a small amount of sample and appears predictive of cytotoxicity and pesticidal activity (Ghisalberti, 1993), and since its introduction the method has been used for bioassay of guided isolation of active antitumor and cytotoxic agent trilobacin from the bark of Asimina triloba (Zhao et al., 1992), cisannonacin from Annona muricata (Rieser et al., 1996), evaluation of acute toxicity of medicinal plants from Kenya biodiversity (Nguta et al., 2012), comparative bioassay of plants different parts (Kaniz et al., 2013) and lethality of Thai medicinal plants in the family Meliaceae. Thus, the aim of this method is to provide a front-line screening that can be backed up by more specific and more expensive bioassay once the active compound is isolated (Siriton et al., 2004).

M. elliptica is a medicinal plant used in Malaysia (locally known as Mengkudu kecil in Malay), it is a shrub or small tree which could reach $5 \mathrm{~m}$ high growing in newly developed areas or in bushes throughout the Malay Peninsula. The leaves are narrowly elliptic or oblanceolate shortly acuminate, with a long, narrow base measuring approximately $15 \mathrm{~cm}$ long and $3 \mathrm{~cm}$ wide with 7 pairs of nerves and $1 \mathrm{~cm}$ long petiole (Zakaria \& Mohd, 2010). Traditionally, parts of the plant are being utilised in various ways for many health troubles and ailments, the shoot is eaten with rice to help increase appetite, it is also eaten to help treat headache, cholera, diarrhoea especially when combined with fever.

The paste of the pounded leaves is applied to the anus for treating piles and is also smeared over with oil heated and then applied over the body for fever, enlarged spleen, wounds and postpartum period, and a lotion of leaves is also rubbed on the body after childbirth (Burkil, 1966; Zakaria \& Mohd, 2010). M. elliptica has been reported to have antioxidant activities (Subramaniam et al., 2003), antibacterial and cytotoxic activities (Ali et al., 2000), and contains anthraquinones (Ismail et al., 1997; Ali et al., 2000). Survey has shown that the leaf is applied to open wounds and the anus indicating a contact with exposed body cells, which might be a medium for fungal or bacterial infections, or being harmful to the cells, thus this work (an extract 
from an ongoing research investigating the antidiabetic effects of M. elliptica, since wound healing is essential in diabetes) is designed to assess the cytotoxic activities of the leaves and root extracts of $M$. elliptica with regards to advancing the efficacy of the plant in the treatment of ailments (especially diabetes).

\section{MATERIALS AND METHODS}

\section{Plant Materials}

Freshly harvested leaves and root of $M$. elliptica were used for the preparation of the crude extracts. They were collected from an uncultivated farm land in Limbang-Sarawak and was identified and authenticated in FRST Universiti Malaysia Sarawak by Prof. Dr. Zaini B. Assim and were given a voucher specimen number WH/MEL015/03 and WH/MER015/04, respectively. They were dried under room temperature.

\section{Preparation of Extracts}

The freshly dried leaves and roots of $M$. elliptica were grounded into powdered form using the laboratory grinder machine. Serial extraction was done using four different solvent systems (n-hexane, DCM, ethyl acetate and methanol). $100 \mathrm{~g}$ of the powdered sample was weighed into an Erlenmeyer flask and each solvent (three times the weight of the extracts) was added. The solution was covered and shaken at time interval of an hour and then allowed to stand for 5-7 days at room temperature. The mixture was then filtered using Whatman filter paper No.4 and the solvent was evaporated using a rotary evaporator under reduced pressure below $60^{\circ} \mathrm{C}$. It was then stored in refrigerator until use.

\section{Hatching of Brine Shrimp}

$1.5 \mathrm{~g}$ of Artemia salina cysts was placed in one side in $1 \mathrm{~L}$ capacity glass container (hatching chamber) containing seawater (collected from Damai beach in Kuching-Sarawak) and aerated, air pump was fitted to the water in the container to ensure complete aeration of the cysts and fluorescence lamp was placed at the other side of the container, this is to attract the newly hatched nauplii. After 48 hours of incubation at room temperature $\left(27-29^{\circ} \mathrm{C}\right)$, under continuous illumination of fluorescence lamp, the newly hatched freeswimming nauplii were harvested from the glass container. The freshly hatched free-swimming nauplii were used for the bioassay.

\section{Preparation of Test Samples}

An alternative dilution procedure developed by McLaughlin et al. (1998) was taken in the preparations of the extract concentrations. 20 $\mathrm{mg}$ of each extract (leaves and root) was dissolved in $2 \mathrm{ml}$ dimethyl sulfoxide (DMSO) and from this solution, 5, 25, 50, 250 and 500 $\mu 1$ were transferred into pre-marked vials to give a lower series of chosen concentration of $1,5,10,50$ and $100 \mathrm{ppm}$, respectively. They were left overnight for the solvent to evaporate. $0.2 \mathrm{ml} \mathrm{DMSO}$ and about $4 \mathrm{ml}$ of seawater were added to each pre-marked vial and 10 brine shrimps were carefully taken with micropipette and introduced into each vial. This was done in triplicates making a total of 30 brine shrimps per dilution and the mixture was adjusted to a final volume of 5 $\mathrm{ml}$ with seawater.

Seawater was added to DMSO in a different set of 3 pre-marked vials and 10 brine shrimps were carefully taken with micropipette and introduced into each microplate, this was used as the control groups. If the brine shrimp in these microplates shows a rapid mortality rate, then the test is considered invalid as the nauplii might have died due to some reasons other than the cytotoxicity of the extracts. The setup was allowed uncovered for $24 \mathrm{~h}$ under constant illumination of fluorescent lamp and with circumspection that the microplates are not overheated by the lamp. Numbers of surviving nauplii were then counted with an aid of a hand lens and recorded.

\section{Statistical Analysis}

The data obtained was analysed using statistical software SPSS 22 for probit analysis to determine the $\mathrm{LC}_{50}$ of the plant at $95 \%$ confidence intervals $(\mathrm{p}<0.05)$.

\section{RESULTS AND DISCUSSION}

The lethality concentration $\mathrm{LC}_{50}$ was assessed at $95 \%$ confidence interval using probit analysis. The lethality of a test sample on a simple zoological organism like the brine shrimp (Artemia Salina) has been utilized by many researchers, and has turned out to be a useful tool in screening various 
Table 1. Average death of Artemia salina at different concentrations of the leaves extract of M. elliptica

\begin{tabular}{|c|c|c|c|c|c|c|c|}
\hline \multirow[t]{2}{*}{$\begin{array}{l}\text { Solvent } \\
\text { system }\end{array}$} & \multicolumn{6}{|c|}{$\frac{\text { Average death of Artemia salina }}{\text { Concentration } \mathrm{ppm}(\mu \mathrm{g} / \mathrm{mL})}$} & \multirow[t]{2}{*}{$\begin{array}{r}\mathrm{LC} 50 \\
\mu \mathrm{g} / \mathrm{mL}\end{array}$} \\
\hline & Control & 1 & 5 & 10 & 50 & 100 & \\
\hline Hexane & 0 & $2 \pm 0.57$ & $3 \pm 0.57$ & $4 \pm 0.57$ & $5 \pm 0.57$ & $7 \pm 0.57$ & 35.483 \\
\hline DCM & 0 & $1 \pm 0.57$ & $3 \pm 0.57$ & $3 \pm 0.57$ & $4 \pm 0.57$ & $5 \pm 0.00$ & 47.745 \\
\hline Ethyl acetate & 0 & $1 \pm 0.57$ & $2 \pm 0.57$ & $3 \pm 0.57$ & $4 \pm 0.57$ & $4 \pm 0.00$ & 62.250 \\
\hline Methanol & 0 & $2+0.57$ & $3+0.57$ & $4+0.57$ & $4+0.57$ & $7+0.57$ & 36.069 \\
\hline
\end{tabular}

* Mean \pm SD. $\mathrm{n}=30$

Table 2. Average death of Artemia salina at different concentrations of the root extract of M. elliptica

\begin{tabular}{|c|c|c|c|c|c|c|c|}
\hline \multirow[t]{2}{*}{$\begin{array}{l}\text { Solvent } \\
\text { system }\end{array}$} & \multicolumn{6}{|c|}{$\frac{\text { Average death of Artemia salina }}{\text { Concentration ppm }(\mu \mathrm{g} / \mathrm{mL})}$} & \multirow[t]{2}{*}{$\begin{array}{r}\mathrm{LC} 50 \\
\mu \mathrm{g} / \mathrm{mL}\end{array}$} \\
\hline & Control & 1 & 5 & 10 & 50 & 100 & \\
\hline Hexane & 0 & $2 \pm 0.57$ & $3 \pm 0.57$ & $4 \pm 0.57$ & $5 \pm 0.57$ & $6 \pm 0.57$ & 58.483 \\
\hline DCM & 0 & $1 \pm 0.57$ & $2 \pm 0.57$ & $3 \pm 0.57$ & $5 \pm 0.57$ & $6 \pm 0.00$ & 65.745 \\
\hline Ethyl acetate & 0 & 0 & $2 \pm 0.57$ & $2 \pm 0.57$ & $3 \pm 0.57$ & $4 \pm 0.00$ & 102.250 \\
\hline
\end{tabular}

* Mean \pm SD. $\mathrm{n}=30$

chemical compounds found in various bioactivities, therefore this survey is aimed at offering a front-line screen that can be backed up by more specific bioassay. From the outcome of this study all the fractions of the extracts exhibited cytotoxic activities, however, n-hexane fraction of the leaves extract exhibited the highest brine shrimp lethality with $\mathrm{LC}_{50}$ value of $35.483 \mathrm{ppm}$ $(\mu \mathrm{g} / \mathrm{ml})$ followed by the methanol fraction with $\mathrm{LC}_{50}$ value $36.069 \mathrm{ppm} \quad(\mu \mathrm{g} / \mathrm{ml})$ and ethyl acetate exhibited the lowest activity with $\mathrm{LC}_{50}$ value $62.250 \mathrm{ppm}(\mu \mathrm{g} / \mathrm{ml})$ (Table.1). The result also shows the methanol fraction of the root extract exhibited the highest lethality activity with $\mathrm{LC}_{50}$ value of $39.259 \mu \mathrm{g} / \mathrm{ml}$ followed by $\mathrm{n}$-hexane with $\mathrm{LC}_{50}$ value of $58.483 \mathrm{ppm}(\mu \mathrm{g} / \mathrm{ml})$, and ethyl acetate exhibited the lest lethality activity with $\mathrm{LC}_{50}$ value of $102.250 \mathrm{ppm}(\mu \mathrm{g} / \mathrm{ml})$ (Table 2$)$.

The lethality observed in this study was found to be directly proportional to the concentration of the extracts ranging from the lowest $(1 \mu \mathrm{g} / \mathrm{ml})$ to the highest $(100 \mu \mathrm{g} / \mathrm{ml})$. This concentration dependent increment in mortality rate of the brine shrimp nauplii is an indication of cytotoxic principles in the extracts and that $M$. elliptica contains cytotoxic active principles. The upshot of the survey also showed methanol and hexane fractions in both the leaves and roots exhibited high cytotoxic effects in the same concentration gradient manner, this finding is congruent with the works of various authors who reported on the cytotoxic effects of the $M$. elliptica in methanol and hexane fractions using brine shrimp (Ali et al., 2000; Apu et al., 2010; Ihsan-Ul-Haq et al., 2012; Kaniz et al., 2013).

However, the findings of this study do not justify the full cytotoxic potency of the plant. A more specific bioassay method is suggested to determine the cytotoxicity level of the plant. Brine shrimp bioassay has been proven as true, practical and economical method for determination of bioactivities of synthetic compounds (Almeida et al., 2002).

\section{CONCLUSION}

In this work, there was a concentration dependent increment in mortality rate of the brine shrimp as well as high cytotoxic activities of the methanol and hexane fractions 
for both leaves and roots respectively. However, this alone provides a validation of the cytotoxic effect of the plant extracts which might indicate a baseline information in understanding the possible medicinal value and further clinical studies are needed.

\section{ACKNOWLEDGEMENT}

The authors are grateful to UNIMAS for the grant provided for this research work that was supported by grant number F07(DPP19)/1187/2014(19).

\section{REFERENCES}

Ali, A.M., Ismail, N.H., Mackeen, M.M., Yazan, L.S., Mohamed, S.M., Ho, A.S. \& Lajis, N.H. (2000). Antiviral, cytotoxic and antimicrobial activities of anthraquinones isolated from the roots of Morinda elliptica. Pharmaceutical Biology, 38(4): 298-301.

Almeida, P.A., Silva, T.M.S. \& Echevarria, A. (2002). Mesoinin 5-alkyll,3-dithiolium4thiolates: synthesis and brine shrimp toxicity. Heterocyclic Communication, 8:593-600.

Apu, A.S., Muhit, M.A., Tareq, S.M., Pathan, A.H., Jamaluddin, A.T.M. \& Ahmed, M. (2010). Antimicrobial Activity and Brine Shrimp Lethality Bioassay of the Leaves Extract of Dillenia indica Linn. Journal of Young Pharmacy, 2(1): 5-0-53.

Ghisalberti, E.L. (1993). Detection and isolation of bioactive natural products. In S.M. Colegate and R.J. Molyneux (Eds.), Bioactive natural products. Detection, isolation and structural elucidation. Boca Raton: CRC Press. Pp 15-18.

Ihsan-Ul-Haq, Abdul M., Ibrar A., Izhar H., Maryam J. \& Bushra M. (2012). Antibacterial activity and Brine Shrimp Toxicity of Artemisia Dubia Extract. Pakistan Journal of Botany, 44(4): 14871490.

Ismail, N.H., Ali, A.M., Aimi, N., Kitajima, M., Takayama, H. \& Lajis, N.H. (1997). Anthraquinones from Morinda elliptica. Phytochemistry, 45: 1723-1725.
Kaniz, F.U., Samina, M., Gulshanara, B. \& Kaiser, H. (2013). Comparative brine shrimp lethality bioassay of different plant parts of Bauhinia purpurea L. Journal of Pharmaceutical Science and research, 15(10): 190-192.

McLaughlin, J.L., Rogers, L.L. \& Anderson, J.E. (1998). The use biological assays to evaluate botanicals. Drug Information Journal, 32: 513-524.

Meyer, B.N., Ferrigni, R.N., Putnam, J.E., Jacobson, L.B., Nicholas, D.E. \& McLaughlin, J.L. (1982). Brine shrimp: A convenient general bioassay for active plant constituents. Planta Medica, 45: 31-34.

Nguta, J.M., Mbaria, J.M., Gakuya, D.W., Gathumbi, P.K., Kabasa, J.D. \& Kaima, S.G. (2012). Evaluation of acute toxicity of crude extracts from Kenya biodiversity using brine shrimp, Artemia salina L. (Artemiidae), The Open Conference Proceedings Journal, 3: 30-34.

Rieser, M.J., Gu, Z.M., Fang, X.P., Zeng, L., Wood, K.V. \& McLaughlin, J.L. (1996). Five novel mono-tetrahydrofuran ring acetogenins from the seeds of Annona muricata. Journal of Natural Products, 59: 100-108.

Siriton, P., Pinyupa, P., Nasit, P., Siriluk, R. \& Onrudee, M. (2004) Brine shrimp lethality activity of Thai medicinal plants in the family Meliaceae. Naresuan University Journal, 12(2): 13-18.

Subramaniam, V., Adenan, M.I., Ahmad, A.R. \& Sahdan, R. (2003). Natural antioxidants: Piper sarmentosum (kadok) and Morinda elliptica (Mengkudu). Malays Journal of Nutrition, 9(1): 41-51.

Zakaria, M. \& Mohd, M.A. (2010). Traditional Malay medicinal plants, Kuala Lumpur: Institute Terjemahan nasional Malaysia. Pp 28.

Zhao, G., Hui, Y., Rupprecht, J.K., McLaughlin, J.L. \& Wood, K.V. (1992). Additional bioactive compounds and trilobacin, a novel highly cytotoxic acetogenin from the bark of asimina tribola. Journal of Natural Products, 55: 347-356. 